\title{
Emissions of nitrogen dioxide from modern diesel vehicles
}

\author{
G. A. Bishop \& D. H. Stedman \\ Department of Chemistry and Biochemistry, \\ University of Denver, Colorado, USA
}

\begin{abstract}
The traditional on-road emissions remote sensing technique has been enhanced with the ability to monitor not only $\mathrm{CO}, \mathrm{CO}_{2}, \mathrm{HC}$ and $\mathrm{NO}$, but also $\mathrm{SO}_{2}, \mathrm{NH}_{3}$ and $\mathrm{NO}_{2}$. Modern diesel powered vehicles, particularly in Japan and Europe are equipped with diesel particle filters (DPFs). These traps are frequently designed to be self regenerating by means of a prior catalytic oxidation of the exhaust $\mathrm{NO}$ to $\mathrm{NO}_{2}$. Because of this intentional conversion to $\mathrm{NO}_{2}$, the ratio of $\mathrm{NO}_{2}$ to $\mathrm{NO}$ in modern diesel vehicles is very different from older vehicles. The detailed results of measurements from several thousand vehicles measured in Japan, Austria and Sweden in 2006 and 2007 will be compared to results from the USA where there are very few vehicles equipped with DPFs. The overall picture is vehicles without DPFs in the USA emit between 5 and $10 \% \mathrm{NO}_{2}$ while vehicles with DPFs are often observed at $50 \% \mathrm{NO}_{2}$ by moles. This, together with the overall $\mathrm{NO}_{\mathrm{x}}$ reductions has strong negative implications for local photochemical ozone production.
\end{abstract}

Keywords: nitrogen dioxide, automobile emissions, on-road remote sensing.

\section{Introduction}

In his review of diesel exhaust emissions control strategies, Lemaire [1] suggests that nitrogen dioxide $\left(\mathrm{NO}_{2}\right)$ was forgotten as a separate component of the $\mathrm{NO}_{\mathrm{x}}$ emissions from diesel vehicles. He further suggests that this omission has caused the observed increases in $\mathrm{NO}_{2}$ and ozone in a number of cities in Europe. For instance, he shows a very strong correlation between the imposition of diesel particle filters (DPFs) on London buses with the increase in the $\mathrm{NO}_{2} / \mathrm{NO}_{\mathrm{x}}$ ratio in London. Carslaw et al. [2] draw the same conclusion. 
The DPF is an extremely effective means to achieve particle reduction goals. However, these traps are bound to become clogged with carbon particles in normal use and must be regenerated in order to maintain a useful in-service lifetime. The most economical method of regeneration makes use of the fact that $\mathrm{NO}_{2}$ can oxidize carbon (soot) to gaseous products $\left(\mathrm{CO}\right.$ and $\left.\mathrm{CO}_{2}\right)$ at typical diesel exhaust system temperatures. This regeneration is however not adequate with the normal $\mathrm{NO}_{2} / \mathrm{NO}_{\mathrm{x}}$ ratio in diesel exhaust (between $6 \%$ ad $9 \%$ [3]). As a result, an intentional catalytic conversion of $\mathrm{NO}$ to $\mathrm{NO}_{2}$, using the excess oxygen from the engine, is carried out in the exhaust system of these DPF equipped vehicles in order to enhance the $\mathrm{NO}_{2} / \mathrm{NO}_{\mathrm{x}}$ ratio. Some diesel vehicles not equipped with DPF, nevertheless are equipped with an oxidation catalyst which also has the effect of increasing the $\mathrm{NO}_{2} / \mathrm{NOx}$ ratio.

The reasons for concern about nitrogen dioxide emissions arise in part from observations of ambient air concentrations in urban core areas [2]. These observations generally show decreasing concentrations of total $\mathrm{NO}_{\mathrm{x}}\left(\mathrm{NO}+\mathrm{NO}_{2}\right)$ but increasing concentrations of $\mathrm{NO}_{2}$. Both of these observations, but particularly the $\mathrm{NO}_{2}$ increase, are of concern to air pollution photochemistry because $\mathrm{NO}_{2}$ leads directly, through solar photolysis, to ozone formation while NO initially removes ozone in the process of becoming $\mathrm{NO}_{2}$. Lowering $\mathrm{NO}_{\mathrm{x}}$ concentrations enhances urban ozone [4] while directly emitting $\mathrm{NO}_{\mathrm{x}}$ as $\mathrm{NO}_{2}$ further enhances ozone and many other manifestations of photochemical smog. An attempt to simplify the complexity of these photochemical processes was published by Stedman [5] and in a poster [6]. The two preceding references are available from the web site www.feat.biochem.du.edu and click on "Publications List". Our work and others suggests that modern gasoline powered vehicles emit less than $1 \%$ of their $\mathrm{NO}_{\mathrm{x}}$ as $\mathrm{NO}_{2}$. For instance, Heeb et al. measured emissions of twenty Euro III and Euro IV gasoline powered vehicles in a dynamometer based study [7]. Using high-speed sampling and a mass spectrometric analytical method, they arrived at the same conclusion.

\subsection{On road remote sensing}

On road remote sensing enables fuel-based emission measurements to be made from a very large number of vehicles driving in a real on-road situation. Typically the systems can monitor the emissions of between 3000 and 10000 vehicles per day. The system measures emissions in ratio to fuel burned. Results are frequently reported in gm of pollutant per $\mathrm{kg}$ of fuel. The recent development of on-road emission remote sensing for $\mathrm{SO}_{2}, \mathrm{NH}_{3}$ and $\mathrm{NO}_{2}$ is described by Burgard et al. [8]. The first two gases are measured in the deep ultraviolet (200$220 \mathrm{~nm}$ ) using the same diode array spectrometer used for $\mathrm{NO}$ at $230 \mathrm{~nm}$. Nitrogen dioxide is monitored by means of its visible absorption at $430 \mathrm{~nm}$ using an identical spectrometer but set to monitor at these longer wavelengths. The spectroscopic matrix deconvolution process by means of which these analyses are carried out has been described by Bishop and Stedman [9]. In order to monitor heavy duty diesel vehicles in the USA, the same system which is normally used to monitor passing light duty vehicles in under one second each is 
placed upon scaffolding with the optical beam approximately three meters above the ground. A lower level optical trigger is added to initiate plume measurement.

The instrumentation with this new capability has been used on-road in the U.S.A., Japan, Austria and Sweden. In the USA very few diesel vehicles are equipped with either DPF or oxidation catalysts. The comparison study, also reported herein, [10] was carried out on a relatively small fleet of diesel school buses some of which had recently been retrofitted with either DPF or diesel oxygenation catalysts (DOC). Japan, Austria and Sweden, where some of these reported remote sensing observations have been made, have required new model year diesel vehicles to significantly lower their particle emissions using DPF technology.

\section{Experimental methods}

More than 40,000 measurements were made in Japan in May and June of 2006. We did not obtain vehicle model year (MY), but did obtain a vehicle classification number from the license plate. Vehicles classified in the 100 series are mostly more or less heavy duty diesel vehicles. Vehicles in the 500 series are mostly gasoline fuelled automobiles.

More than 15,000 Measurements were made in Sweden in June 2007 [11] while a similar number of measurements were made in Austria shortly afterwards.

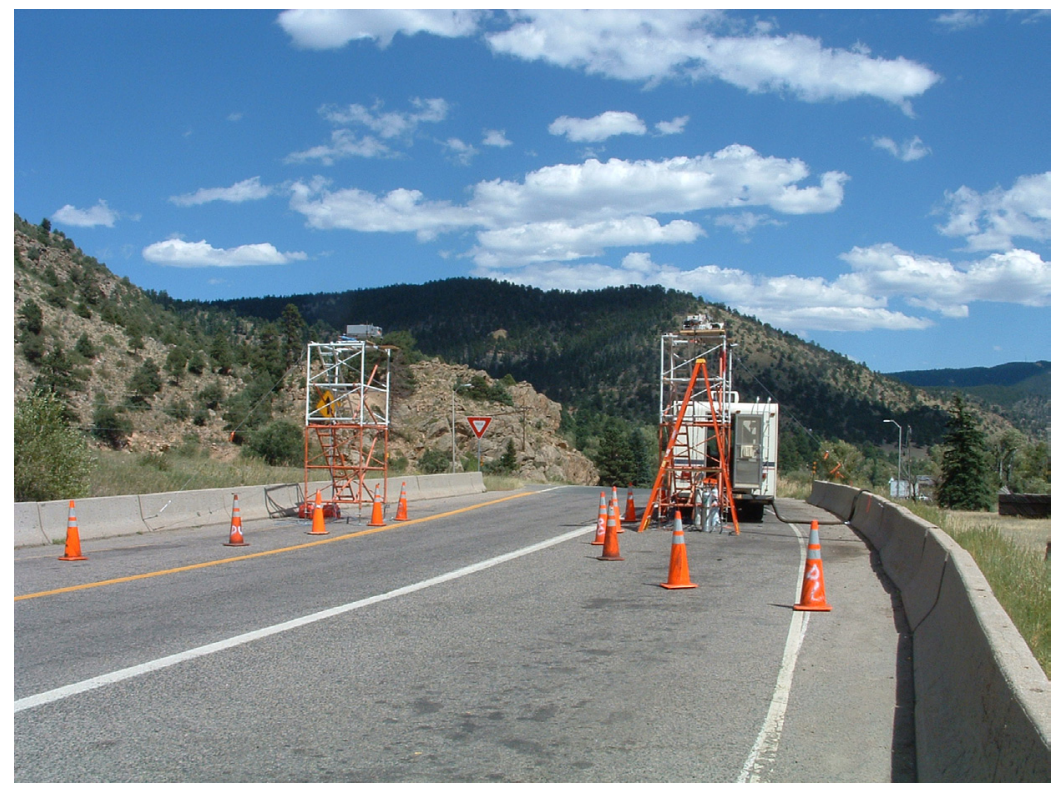

Figure 1: $\quad$ Photograph from Colorado showing the necessary scaffolding and the three calibration cylinders. 
Figure 1 shows the instrumentation as set up to monitor truck tractor emissions in Colorado. The three gas cylinders contain the necessary calibration gas mixtures. The main calibration gas cylinder contains $\mathrm{CO}, \mathrm{CO}_{2}, \mathrm{NO}$, Propane and $\mathrm{SO}_{2}$ with the balance nitrogen. The two secondary cylinders contain in one, a known mixture of $\mathrm{NO}_{2}$, and $\mathrm{CO}_{2}$ balance air (stored $\mathrm{NO}_{2}$ is incompatible with both propane and NO) and, in the second, a known mixture of $\mathrm{NH}_{3}$ and propane in nitrogen because $\mathrm{NH}_{3}$ and $\mathrm{CO}_{2}$ are incompatible. All calibration gases are supplied by Scott Specialty Gases of Longmont CO.

\section{Results and discussion}

Figure 2 shows, in histogram form, the data from the 2006 study in Japan. It is quite noticeable that the gasoline powered vehicles (class 5, mean $\mathrm{NO}_{2} 0.1$ and median $0.05 \mathrm{~g} / \mathrm{kg}$ ) have lower $\mathrm{NO}_{2}$ as well as lower total $\mathrm{NO}_{\mathrm{x}}$ than the diesel (class 1 , mean $\mathrm{NO}_{2} 1.9$ and median $1.4 \mathrm{~g} / \mathrm{kg}$ ) and a very much lower $\mathrm{NO}_{2} / \mathrm{NO}_{\mathrm{x}}$ ratio. Several of the diesel trucks emit more than $50 \%$ by mass of their $\mathrm{NO}_{\mathrm{x}}$ as $\mathrm{NO}_{2}$. For these comparisons $\mathrm{NO}_{\mathrm{x}}$ is given the mass of $\mathrm{NO}_{2}$ although the majority gas emitted is most often NO.

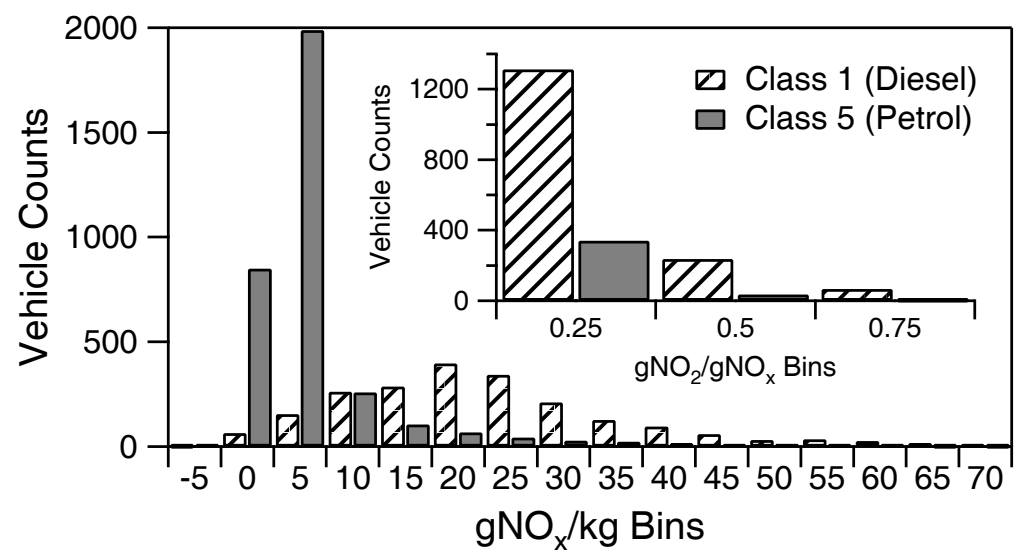

Figure 2: Histogram plots from Japan showing that the class 5 vehicles (cars) have very significantly less $\mathrm{NO}_{2}$ and $\mathrm{NO}_{\mathrm{x}}$ emissions than the class 1 (trucks).

Figure 3 shows a comparison between $\mathrm{NO}_{\mathrm{x}}$ emissions from light duty gasoline powered vehicles measured in Sweden [11] and $\mathrm{NO}_{\mathrm{x}}$ emissions measured in Denver in the same year [12] and using approximately the same model year groupings. The measured $\mathrm{NO}_{2}$ emissions (not shown) from both fleets are not statistically distinguishable from zero. A conservative error analysis suggests less than $2 \%$. The other phenomenon, very noticeable from this Figure, is the amazingly successful reduction of $\mathrm{NO}_{\mathrm{x}}$ emissions over the about 20 year period shown. This observation is cause for congratulations all round, 
because the results not only point to the success of the European and U.S. regulations in reducing automobile emissions, but also to the success of on-road remote sensing in quantitatively demonstrating these phenomena. If the on-road data were significantly contaminated with noise, then these very significant differences would not be observed. The reductions in the U.S., although also dramatic, seem to be somewhat less successful than in Europe over the same time period.

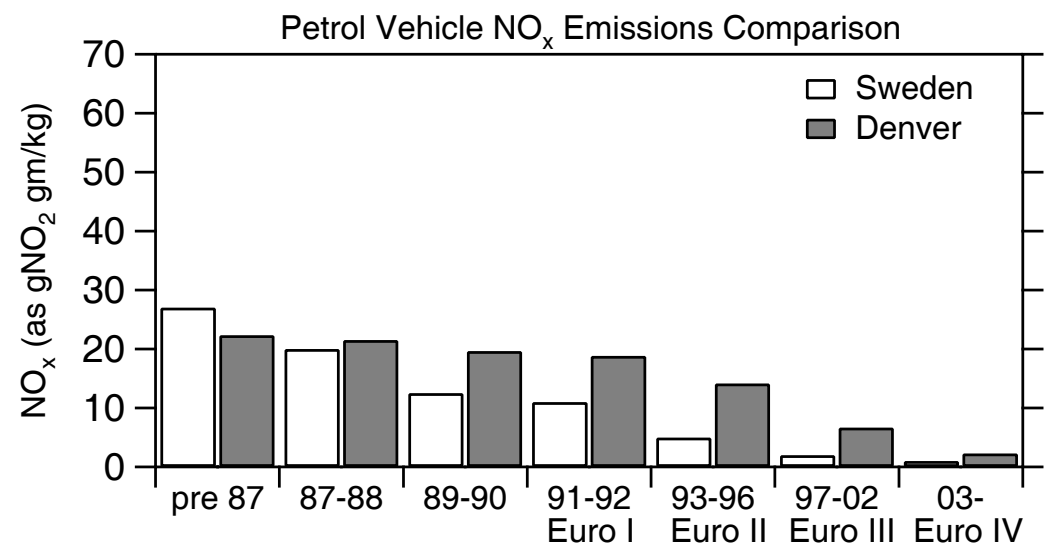

Figure 3: $\quad \mathrm{NO}_{\mathrm{x}}$ emissions from petrol (gasoline) light duty vehicles in 2007.

Figure 4 shows $\mathrm{NO}_{\mathrm{x}}$ and $\%$ of $\mathrm{NO}_{\mathrm{x}}$ as $\mathrm{NO}_{2}$ from medium duty diesel bus vehicles in Sweden compared to a recently reported study from Washington State on retrofitted School Buses [10]. It is very noticeable that the highest $\mathrm{NO}_{\mathrm{x}}$

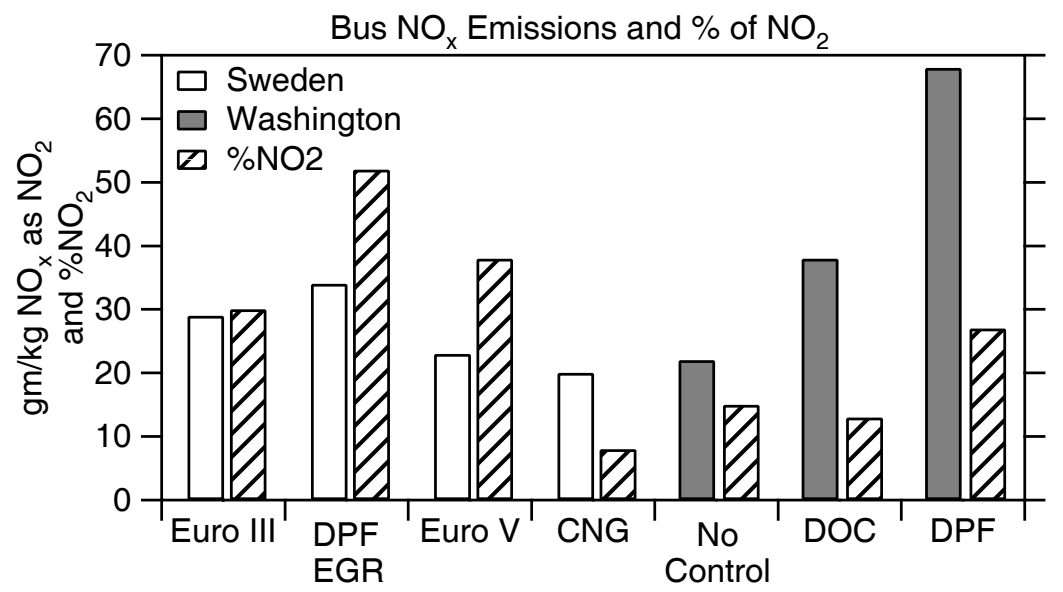

Figure 4: The $2007 \mathrm{NO}_{\mathrm{x}}$ emissions and $\mathrm{NO}_{2} \%$ for buses in the USA and Sweden. 
emissions in this entire manuscript (by almost a factor of two) is the DPF equipped school buses in Washington State. It was reported that while the retrofits on these school buses were underway, there were several cases of filter clogging and this caused many of the DPFs to be removed (as worthless) and replaced with DOC on several fleets. This problem may have arisen because the duty cycle on school buses is relatively light load and frequent stops. The system may rarely become hot enough even for $\mathrm{NO}_{2}$ to regenerate. We speculate that the retrofit contractor, becoming aware of this problem chose to solve it by increasing the $\mathrm{NO}_{\mathrm{x}}$ emissions (and possibly the vehicle power) and thus generating enough excess $\mathrm{NO}_{2}$ that adequate regeneration could take place despite the light duty cycle.

The last Figure 5 shows heavy duty diesel truck $\mathrm{NO}_{\mathrm{x}}$ emissions and $\% \mathrm{NO}_{2}$ compared to a U.S. study [3] and shows $\mathrm{NO}_{\mathrm{x}}$ and $\%$ of $\mathrm{NO}_{\mathrm{x}}$ as $\mathrm{NO}_{2}$ from light duty diesel vehicles in Sweden. Comparing Figures 3 and the last three bars in Figure 5. it is apparent that the modern fleet of light duty diesel vehicles in Europe emit very significantly more $\mathrm{NO}_{\mathrm{x}}$ than their gasoline (petrol) fuelled counterparts. Furthermore, a very significant percentage of their emissions is observed to be in the form of $\mathrm{NO}_{2}$. This is presumably the result of DPF or DOC exhaust aftertreatment equipment on these cars.

It is also apparent from Figures 4 and 5 that, per $\mathrm{kg}$ of fuel, the trucks and buses in Sweden do not have very different $\mathrm{NO}_{\mathrm{x}}$ emissions although the \% of $\mathrm{NO}_{2}$ is quite different. The Euro 2,3 and 4 standards for the trucks do not seem to have resulted in significant on-road $\mathrm{NO}_{\mathrm{x}}$ reductions.

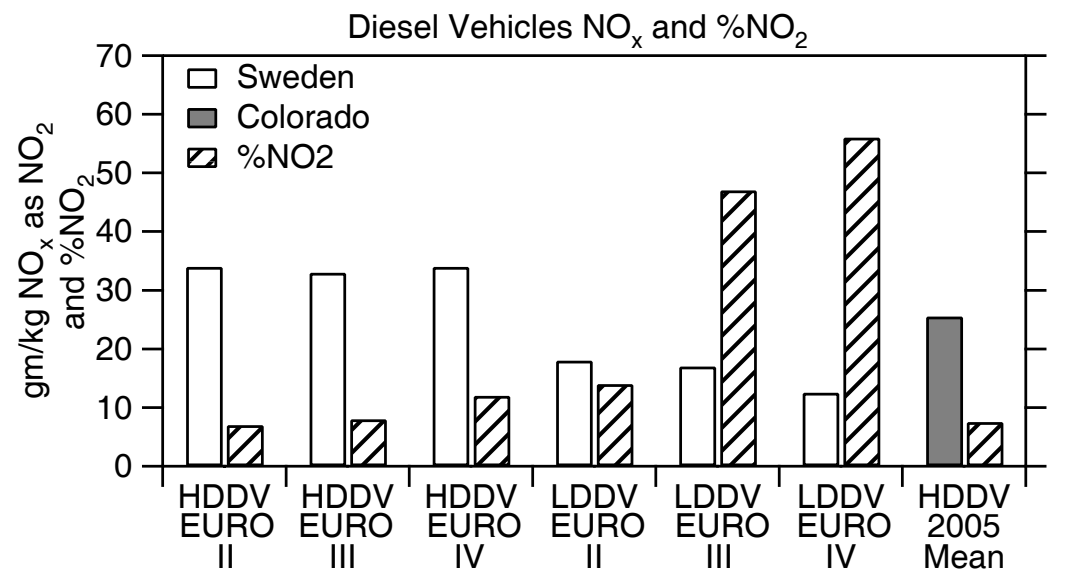

Figure 5: $\quad \mathrm{NO}_{\mathrm{x}}$ emissions and \% of $\mathrm{NO}_{2}$ for diesel HDDV and LDDV in Sweden and HDDV in the USA.

The fact that DPF equipped diesel vehicles show evidence of very large $\mathrm{NO}_{2} / \mathrm{NO}$ ratios compared to pre-control on-road vehicles is apparent from these data. Our expectation was that the U.S.A. retrofit systems would also have shown evidence of reduced total $\mathrm{NO}_{\mathrm{x}}$ emissions. At least in the case of the 
Washington State school buses, it seems that the DPF fleet have higher overall $\mathrm{NO}_{\mathrm{x}}$ emissions as well as a much larger $\mathrm{NO}_{2} / \mathrm{NO}$ ratio.

$\mathrm{NO}$ and $\mathrm{NO}_{2}$ emissions were monitored at three sites in Austria in the summer of 2007. The truck fleet showed relatively low $\mathrm{NO}_{2} / \mathrm{NO}_{\mathrm{x}}$ ratios, for instance $50 \%$ of the fleet showed a ratio lower than 0.1 . Only at the highest load site was the highest $5 \%$ of the vehicles measured with $\mathrm{NO}_{2} / \mathrm{NO}_{\mathrm{x}}>0.5$. By contrast, and not unlike the situation in Sweden, the $85 \%$ diesel car fleet showed very high $\mathrm{NO}_{2} / \mathrm{NO}_{\mathrm{x}}$ ratios. At all three sites the top ten percent of the vehicles were all measured with a $\mathrm{NO}_{2} / \mathrm{NO}_{\mathrm{x}}$ ratio of above 0.7 and at the highest load site $50 \%$ of the whole fleet (gasoline included) were measured above a ratio of 0.5 .

\section{References}

[1] Lemaire, J., How to select efficient diesel exhaust emissions control strategies for meeting air quality targets in 2010. Österreichische Ingenieur und Architekten-Zeitschrift 152 . pp1-12 Heft 1-3, 2007.

[2] Carslaw, D.C., Beevers, S.D. \& Bell, M.C, Risks of exceeding the hourly EU limit value for nitrogen dioxide resulting from increased road transport emissions of primary nitrogen dioxide. Atmospheric Environment, 41 pp. 2073-2082, 2007.

[3] Burgard, D.A., Bishop, G.A., Stedman, D.H., Gessner, V.H., \& Daeschlein C., Remote Sensing of In-Use Heavy-duty Diesel Trucks, D.A. Burgard, , Environ. Sci. Technol., 40, pp. 6938-6942, 2006.

[4] Chow, J.C. Introduction to special topic: weekend and weekday differences in ozone levels EM July pp. 16-25 2003.

[5] Stedman, D.H. Photochemical ozone formation, simplified, Environ. Chem., 1, pp. 65-66, 2004.

[6] Stedman, D.H., The Weekend Effect: the science suggests that we are embarking on an expensive policy which will harm the environment, Poster Presented at the 2006 Diesel Engine-Efficiency and Emissions Research (DEER) Conference, Detroit, MI, August 20 - 24, 2006 available from www.feat.biochem.du.edu/reports.

[7] Heeb, N.V., Saxer, C.J., Forss, A-M., \& Brühlmann, Trends of NO-, $\mathrm{NO}_{2-}$, and $\mathrm{NH}_{3}$-emissions from gasoline-fueled Euro-3- to Euro-4-passenger cars Atmospheric Environment, 42,(10), pp. 2543-2554, 2008.

[8] Burgard, D.A., Dalton, T.A., Bishop, G.A., Starkey, J.R., \& Stedman, D.H. Nitrogen dioxide, sulfur dioxide, and ammonia detector for remote sensing of vehicle emissions, Rev. Sci. Instrum., 77, pp. 014101.1-014101.5, 2006.

[9] Bishop, G.A. \& Stedman, D.H. Signal to Noise Improvements in On-road $\mathrm{NO}, \mathrm{SO}_{2}$, and $\mathrm{NH}_{3}$ Measurements using a Multi-component Classical Least Squares Fitting Approach, Poster presented at the $18^{\text {th }}$ CRC On-road Vehicle Emissions Workshop, San Diego, CA, March 31- April 2, 2008, available from www.feat.biochem.du.edu/reports.

[10] Provinsal, M.N., \& Burgard D.A., Examining gaseous emissions from diesel school buses in Washington State. Proceedings of the $18^{\text {th }}$ CRC OnRoad Vehicle Emissions Workshop, March 31-April 2, 2008. 
[11] Jerksjö, M., Sjödin, Å., Bishop, G.A., Stedman, D.H., On-road emission performance of a European vehicle fleet over the period 1991-2007 as measured by remote sensing. Proceedings of the $18^{\text {th }}$ CRC On-Road Vehicle Emissions Workshop, March 31-April 2, 2008.

[12] Bishop, G.A. \& Stedman, D.H., On-Road Remote Sensing of Automobile Emissions in the Denver Area: Year 6, January 2007, www.feat.biochem.du.edu/publications. 